\title{
The effect of volunteer management mentoring program on mentors' entrepreneurship tendency and leadership self-efficacy
}

\author{
Ebru Külekçi Akyavuz* \\ Educational Science, Kilis 7 Arallk University, Kilis, Turkey \\ ORCID: 0000-0002-2436-8761 \\ Esra Asic1 \\ Educational Science, Kilis 7 Aralık University, Kilis, Turkey \\ ORCID: 0000-0003-0872-9042
}

Article history

Received:

12.06.2020

Received in revised form: 12.11.2020

Accepted:

18.11.2020

Key words:

Mentoring,

entrepreneurship,

leadership self-efficacy
The aim of this study is to examine the effect of participating in the Volunteer Management Mentoring Program on entrepreneurship tendency and leadership self-efficacy. The Volunteer Management Mentoring Program was created by UNICEF and conducted within the scope of the Social Sensitivity course taught at Kilis 7 Aralik University, Turkey. This research was designed as a semi-experimental study with pretest-posttest experiment and control groups. Entrepreneurship Scale and Leadership Self-Efficacy Scale were applied to the students in the experimental and control groups as pretest and posttest. While the students in the experimental group participated in the Volunteer Management Mentoring Program in the process; the students in the control group did not participate in any program. The study group was determined using the criterion sampling method and consisted of 26 university students studying at Kilis 7 Aralik University in the 2019-2020 academic year. 13 students were in the experimental group and 13 in the control group. Personal Information Form, Entrepreneurship Scale for University Students, and Leadership Self-Efficacy Scale were used as data collection tools. The data were analyzed using SPSS package program. Two-factor repeated-measures ANOVA technique was used in the analysis. The findings showed that mentor university students who participated in the Volunteer Management Mentoring Program increased their scores for the entrepreneurship scale after the program was completed. According to another finding, participation in the Volunteer Mentoring Management Program had no significant effect on the leadership self-efficacy scores of mentor students.

\section{Introduction}

With the advent of globalization, the qualities expected of the youth of the $21 \mathrm{st}$ century have changed (Cansoy, 2018). In the 21st century, young people are expected to successfully continue their private, social, and professional lives, adapt to positive changes,

\footnotetext{
*Correspondency: ebrukulekci@kilis.edu.tr_
} 
and react appropriately to negative ones. Therefore, today's youth should have high-level skills and competencies. These high-level skills and competencies expected of young people in the information society are called 21st century skills (Anagün, Atalay, Kılıç, \& Yaşar, 2016). 21st century skills focus on what a person can do with the knowledge they possess (Silva, 2009) and include features that enable individuals to become qualified workers and good citizens (Ananiadou \& Claro, 2009).

Although different classifications have been made about the 21st century skills such as OECD, ATSC21, NRC, NCREL, AACU, ISTE and Iowa Skills Framework, the most accepted among them is the P21 (Partnership for 21st Century Skills) competencies and skills framework (Cansoy, 2018). According to P21, 21st century skills consist of four areas shown in Figure 1. In fact, today, it is not enough for young people to be equipped only with basic science subjects. They should also have skills in learning and innovation, knowledge, media and technology, and life and career. Therefore, creative thinking, producing and applying innovations, being an entrepreneur, reasoning effectively, systematic thinking, analysis and synthesis, solving problems, communicating clearly and effectively, being able to cooperate, being successful in accessing, evaluating, using and managing information, being flexible in adapting to changes, managing time, working independently, managing their own learning process, producing and managing projects, leading others and being responsible are the features expected from the 21st century's youth (Partnership for 21st Century Skills, 2009).

Key issues and 21st century themes:

English, reading and language arts, world languages, art, mathematics, economics, science, geography, history, state and citizenship knowledge, global awareness, financial, economic, business and entrepreneurship literacy, civil literacy, health literacy, and environmental literacy

\section{Learning and innovation skills:}

Creativity and innovation, critical thinking and problem solving, communication and collaboration

\section{P21}

Information, media and technology skills

Information literacy, media literacy, ICT literacy

\section{Life and career skills:}

Flexibility and compatibility, assertiveness and self-management, social and intercultural skills, productivity and accountability, leadership and responsibility

Figure 1. P21 Competencies and skills framework

21 st century skills include knowledge, skills, and tendencies which are regarded as prerequisite for success in the business world of the future (Germaine, Richards, Koeller, \& Schubert-Irastorza, 2016). The acquisition of 21 st century skills by young people is extremely important for both their individual development and their contribution to the development of their country. Educational institutions have important duties in this regard. The transfer of theoretical knowledge to students in lessons is not sufficient for transforming young people 
into individuals with self-confidence, entrepreneurial spirit, leadership skills, sensitivity to the surrounding events, and problem-solving skills. It is not sufficient either for universities to conduct courses that only pave the way for the development of professional knowledge and skills. In order to ensure that young people are equipped with the necessary 21 st century skills, different life-based practices should also be incorporated into education.

One of the life-based practices that can be implemented to help young people acquire $21 \mathrm{st}$ century skills may be the mentoring practices in that regard. Most generally, mentoring is a sharing process. In this process, a person (mentor) uses their knowledge and experience to support the development of another person (mentee) who has relatively less knowledge and experience. Mentoring practices include providing advice, counseling, psychological support, role modeling, and enhancing the individuals' intellectual achievements in their business and social lives (Allen, Eby, \& Lentz, 2006; Rackham Graduate School, 2012a, 2012b). Mentoring practices provide a bridge between the education process and real-life experiences (Barker, 2006). Besdies, mentoring, a network of relationships between the experienced and less experienced individuals, contributes to the development and recognition of leadership skills of the experienced individual. It also helps less experienced individuals to increase their motivation, perform better, and improve themselves (Lo, Thurasamy, \& Liew, 2014).

Considering their contributions to the personal development of both mentor and mentee; mentoring practices are thought to be effective in helping young people acquire 21 st century skills. With this in mind, this study focused on the entrepreneurship tendency and leadership self-efficacy of 21st century skills and examined the effect of a mentoring program, in which university students and middle and high school students were matched, on the mentor university students' entrepreneurship tendency and leadership self-efficacy.

\section{Entrepreneurship}

One of the skills that 21 st century skill frameworks commonly emphasize is entrepreneurship (Cansoy, 2018). Entrepreneurship is defined as creating an activity to perceive and seize an opportunity (Mueller \& Thomas, 2001), creating change and innovation (Morris, Kuratko, \& Covin, 2011), trying to make life more livable, reaching the goal by taking all kinds of risks when opportunities are found (Başol, Dursun, \& Aytaç, 2011). The concept of entrepreneurship refers to not only an economic value, but also a social and cultural situation in the form of contributing to the change of social life, strengthening disadvantaged groups in society, and finding solutions to environmental and social problems (Özdevecioğlu \& Karaca, 2015).

Entrepreneurial individuals are people who are innovative, sensitive to differences, risktaking, persuasive, self-confident, creative, enthusiastic, and able to create new ideas (Abdylaev \& Yurekli, 2018; Aydın, 2015; Caliendo \& Kritikos, 2011; Demir \& Demiryürek, 2018; Moore, 2003; Nybakk \& Hansen, 2008; Shane, 2000; Wickham, 2001). Although the personal characteristics of each entrepreneur are different from each other, entrepreneurial individuals are mostly known as people who can direct and mobilize the individuals around them (Sarıtaş \& Duran, 2017).

Entrepreneurship has been considered an important factor enabling individuals, regions, and countries to develop in social, economic, and cultural areas throughout history (Damar, 2015). For this reason, it is important to raise entrepreneurial individuals for the future of a country. In this context, it is known that various studies have been conducted in universities that examine the effect of entrepreneurship training or entrepreneurship courses on 
entrepreneurship tendency (e.g. Balaban \& Özdemir, 2008; Özdemir, Özgüner, \& Alkış, 2018; Tuncer \& Doğan, 2018). These trainings and courses, which are emphasized to be effective in the development of positive attitudes and behaviors towards entrepreneurship (Uygun \& Güner, 2016), include the concept and characteristics of entrepreneurship and factors affecting it i.e. business idea development, creativity, business planning, financial research and marketing (Özdemir et al., 2018). In the current research, unlike the entrepreneurship trainings and courses where theoretical information about entrepreneurship is transferred to students; the effect of mentoring practices on university students' entrepreneurship tendency was examined. Since mentoring practices include functions such as sharing, leading, and guiding, they may contribute to the development of entrepreneurial personality traits such as persuasion ability, self-confidence, sensitivity, and creativity, thus increasing entrepreneurial tendencies in mentor students.

\section{Leadership self-efficacy}

Another skill highlighted in 21 st century skill frameworks is leadership skill. It includes influencing the followers and providing them with the principle of working together (Paglis \& Green, 2002). The leadership skill, which refers to influencing others and putting them into action (Krug, 1992), is the sum of an individual's knowledge and skills to gather a group of people around specific goals and mobilize them to achieve these goals (Eren, 2004). Leadership self-efficacy, on the other hand, refers to the individuals' confidence in their ability to effectively perform their leadership roles and exhibit the leadership skills necessary to perform the targeted tasks ( $\mathrm{Ng}$, Ang, \& Chan, 2008). Leadership self-efficacy reflects the personal self-efficacy beliefs that one can gather individuals around a goal, direct individuals, and achieve common goals (Cansoy \& Polatcan, 2018). Individuals with leadership selfefficacy are defined as people who take on more responsibility, make effort, and are resistant to difficulties (Paglis \& Green, 2002).

Previous studies showed that leadership skills could be acquired innately and through training as well (Buschlen \& Dvorak, 2011; Külekçi, 2015; Riera, 2009; Robyn, 2005; Rubenstein, 2013; Williams, Townsend, \& Linder, 2005). Although leadership skills can be gained through trainings, it is thought that self-efficacy beliefs related to leadership skills are highly important in transforming these skills into behaviors. Self-efficacy beliefs in the ability to successfully accomplish a task form the basis of personal motivation, success, and happiness (Bandura, Caprara, Barbaranelli, Pastorelli, \& Regalia, 2001). Therefore, having positive selfefficacy beliefs about their leadership skills is a critical issue for young people in the 21st century. It is important to note that the development of self-efficacy beliefs continues throughout life (Bandura, 1994) and one of its sources is individual's own experiences (Bandura, 1986). Hence, a mentoring program, in which university students will have the opportunity to practice their leadership skills, can be expected to have an impact on their leadership self-efficacy. In light of the above information, the aim of the study is to examine the effect of participating in the Volunteer Management Mentoring Program on entrepreneurship tendency and leadership self-efficacy. To this end, answers to the following questions were sought:

(1) Are there any significant differences between the mentor university students in the experiment group and control group in terms of their pre-posttest mean scores for entrepreneurship tendency? 
(2) Are there any significant differences between the mentor university students in the experiment group and control group in terms of their pre-posttest mean scores for leadership self-efficacy?

\section{Method}

\section{Research Model}

The research was designed as a semi-experimental study with pretest-posttest experiment and control groups. In the experimental design, the effect of the method used on the experimental group is investigated based on the results obtained from the pretest and posttest (Büyüköztürk, 2013). The semi-experimental pattern also serves the same purpose. Unlike the experimental design, in the semi-experimental design, participants cannot be randomly assigned to the experimental and control groups (Ekiz, 2003). Semi-experimental design has been preferred in the experimental studies on educational environments since it is difficult to assign participants to groups neutrally (Gay, Mills, \& Airasian, 2005).

Table 1. Experimental pattern process

\begin{tabular}{|c|c|c|c|c|}
\hline Groups & Pretest & Operations & & Posttest \\
\hline Fynerimental & Entrepreneurship Scale & Volunteer & Mentoring & Entrepreneurship Scale \\
\hline $\begin{array}{l}\text { Experimental } \\
\text { Control }\end{array}$ & $\begin{array}{l}\text { Leadership } \\
\text { efficiency Scale }\end{array}$ & $\begin{array}{l}\text { Program } \\
(9 \text { weeks })\end{array}$ & & $\begin{array}{l}\text { Leadership } \\
\text { efficiency Scale }\end{array}$ \\
\hline
\end{tabular}

As seen in Table 1, Entrepreneurship Scale and Leadership Self-Efficacy Scale were applied to the students in the experimental and control groups as pretest and posttest. While the students in the experimental group participated in the Volunteer Management Mentoring Program in the process; the students in the control group did not participate in any program.

\section{Study Group}

The study group consisted of 26 students studying at Kilis 7 Aralik University in the 2019-2020 academic year. The study group was determined using the criterion sampling method. In the study group, those who took the Social Sensitivity course and participated in the Volunteer Management Mentoring Program were included in the experimental group; and those who did not take the course or participate in the program were included in the control group.

Initially, there were 25 (19 female and 6 male) university students who met the criteria for the experimental group, and 16 of them (13 female and 3 male) agreed to fill up the pretest. However, UNICEF decided to exclude the male mentor students from the program because all the mentee students were female. Thusly, in total, 19 female university students joined the program and 13 of them were included in the experimental group.

In order to determine the control group, the pretests were applied to 16 ( 9 female and 7 male) university students who met the criteria for the control group and agreed to fill up the pretest. However, 3 of them did not want to fill up the posttest. Thus, the control group consisted of 13 university students ( 8 female and 5 male). Information on the demographic characteristics of the study group was given in Table 2 . 
Table 2. Demographic characteristics of the participants

\begin{tabular}{|c|c|c|c|c|c|c|c|c|}
\hline \multirow{2}{*}{ Variables } & & & \multicolumn{2}{|c|}{ Experimental } & \multicolumn{2}{|c|}{ Control } & \multicolumn{2}{|c|}{ Total } \\
\hline & & & n & $\%$ & $\mathbf{n}$ & $\%$ & $\mathbf{n}$ & $\%$ \\
\hline \multirow{2}{*}{ Gender } & & Female & 13 & 100 & 8 & 61.5 & 21 & 80.8 \\
\hline & & Male & - & - & 5 & 38.5 & 5 & 19.2 \\
\hline \multirow{6}{*}{$\begin{array}{l}\text { Faculty } \\
\text { Academy }\end{array}$} & & Theology Faculty & - & - & 1 & 7.7 & 1 & 3.8 \\
\hline & & Education faculty & 6 & 46.2 & 1 & 7.7 & 7 & 26.9 \\
\hline & & Faculty of Economics & 1 & 7.7 & 1 & 7.7 & 2 & 7.7 \\
\hline & I & Social Sciences & 2 & 15.4 & 2 & 15.4 & 4 & 15.4 \\
\hline & & Tourism & - & - & 3 & 23.1 & 3 & 11.5 \\
\hline & & $\begin{array}{l}\text { School of Health } \\
\text { Services }\end{array}$ & 4 & 30.8 & 5 & 38.5 & 9 & 36.4 \\
\hline Total & & & 13 & 100 & 13 & 100 & 26 & 100 \\
\hline
\end{tabular}

\section{Data Collection}

Personal Information Form, Entrepreneurship Scale for University Students, and Leadership Self-Efficacy Scale were used as data collection tools. The scales are explained below.

\section{Personal information form}

The personal information form created by the researchers includes questions about information such as the university students' age, gender, department, and grade.

\section{Entrepreneurship Scale for University Students}

The scale, developed by Y1lmaz and Sünbül (2009) to determine the entrepreneurship characteristics of students, consists of 36 items in total. The scores for this 5-point Likert scale (1: Never - 5: Very often) vary between 36 and 180. The higher the score, the higher the entrepreneurship tendency. As a result of the construct validity, the scale was found to have a single-factor structure that explained $47.3 \%$ of the total variance. Factor loadings of the scale range between .44 and .70. Yılmaz and Sünbül (2009) calculated Cronbach's Alpha reliability coefficient of the scale as 90 . In the current study, the Cronbach's Alpha value was .91 for the pretest and .92 for the posttest.

\section{Leadership Self-Efficacy Scale}

The 7-point Likert-type scale developed by Bobbio and Manganelli (2009) consists of 21 items and 6 sub-dimensions [ability to (1) start and lead processes in groups, (2) select effective followers and delegate responsibility, (3) establish and manage interpersonal relationships within the group, (4) exhibit self-awareness and self-confidence, (5) motivate others, and (6) gain consensus among group members]. The scale was adapted into Turkish by Cansoy and Polatcan (2018). The analyses revealed that the single-factor structure of the Turkish version of the scale was valid and reliable $\left(\chi^{2}=388.39, \mathrm{df}=150, \mathrm{RMSEA}=.068, \mathrm{CFI}\right.$ $=.97$, IFI=.97, SRMR = .048, GFI =.89; AGFI=.86). In the adaptation study, Cronbach's Alpha internal consistency coefficient of the Leadership Self-Efficacy Scale was determined as 92. In the current study, Cronbach's alpha value was .93 for the pretest and .97 for the posttest. The scores for the scale vary between 21 and 147. The higher the score, the higher the individuals' beliefs in themselves in demonstrating their leadership behavior. 


\section{Implementation}

The research was carried out at Kilis 7 Aralik University during the fall semester of the 2019-2020 academic year. A questionnaire consisting of Entrepreneurship Scale, Leadership Self-Efficacy Scale, and personal information form was applied to the students in the experimental and control groups in October 2019. Later, the students in the experimental group participated in the 9-week Volunteer Management Program. The students in the control group were not included in any program. Within the scope of the research, the same measurement tools were applied to the experimental and control groups at the same time. The posttests were carried out immediately after the end of the Volunteer Management Program (January 2020). The implementation of the scales took approximately 15 minutes.

\section{Volunteer Management Program}

The program was carried out under the cooperation among UNICEF, Kilis municipality, and Kilis 7 Aralik University. The program was created by UNICEF within the scope of "Community-based practices training for the prevention of child, early, and forced marriages program". In the Volunteer Management Mentoring Program, university students mentor middle and high school students. In this context, each university student was matched with three middle or high school students. The purpose of the program is to ensure that university students and middle and high school students get to know each other, and university students support and guide middle and high school students academically, socially, and culturally. It is also aimed to ensure that mentor university students are instrumental in establishing educational and social goals for the middle and high school students selected from the disadvantaged group.

The Volunteer Management Mentoring Program consisted of two stages and covered a period of 9 weeks.

In the first stage of the program, 25 volunteer university students who took the Social Sensitivity course were determined by their academic advisors. UNICEF provided a 2-day training for the 25 university students and their academic advisors. This training aimed to introduce the Volunteer Management Mentoring Program to the university students and their academic advisors, and to teach them about various issues such as child rights, working with children and adolescents, communicating with children and adolescents, equality and empowerment of girls. The training for university students and their academic advisors were conducted in separate sessions. The training for university students was designed as an interactive program and included various activities such as discussions, role playing, presentation, and games for ice breaking. In addition to the aforementioned issues, the training for academic advisors focused on information about implementation of the program, and roles and responsibilities of the academic advisors during the implementation of the program. After the mentor students were determined, the middle and high school students identified as disadvantaged (with academic failure, lower socioeconomic status, refugee status, etc.) by the municipality were chosen, and each university student (mentor) was matched with 3 middle or high school students (mentees). Mentors and mentees were allowed to get to know each other through an event organized by the university, UNICEF, and the municipality. After the mentor students were matched with the mentee students, the mentor students were asked to organize and carry out various activities for 6 weeks. The objectives of these activities are as follows:

- Ensuring that the mentor and mentee students get to know each other,

- Ensuring that the mentor students set an example for the mentee students 
- Ensuring that the mentee students set goals for future

- Providing opportunities for the university students to take responsibility for others as a mentor

- Ensuring that the mentor students collaborate with different institutions and organizations, and so their communication channels develop.

In line with these objectives, each mentor student planned and implemented activities such as going on a trip to the university, visiting business people, participating in entertaining activities such as going to the cinema, theater, concerts or museums, attending a class in the university, and designing individual activities with middle or high school students. Each activity was planned to cover a week. After the activity, the mentor students took note of their impressions and shared them with their academic advisors. All the activities were evaluated in the middle of the period and at the end of the period.

Within the scope of the program, the researchers took on the roles of coordinating the "Social Sensitivity" course and mentoring a group of university students. The researchers participated in the training programs created by UNICEF.

\section{Data Analysis}

The data were analyzed using SPSS package program, and the statistical significance was set at .05. Two-factor repeated-measures ANOVA technique was used in the analysis. Before starting the analysis, the assumptions of normality and homogeneity of variances were tested.

Shapiro Wilk (SW) normality test was performed in order to test the normality of the pretest and posttest scores obtained from the entrepreneurship and leadership self-efficacy scales in the experimental and control groups. The results of the Shapiro Wilk (SW) normality test were given in Table 3 .

Table 3. Normality analysis results

\begin{tabular}{|c|c|c|c|c|c|c|c|}
\hline \multirow{2}{*}{ Variable } & \multirow{2}{*}{ Groups } & \multicolumn{3}{|c|}{ Pretest score } & \multicolumn{3}{|c|}{ Posttest score } \\
\hline & & SW & df & $p$ & SW & df & $p$ \\
\hline \multirow{2}{*}{ Entrepreneurship } & Experimental & .87 & 13 & .05 & .97 & 13 & .90 \\
\hline & Control & .90 & 13 & .12 & .94 & 14 & .40 \\
\hline Leadership & Experimental & .94 & 13 & .51 & .95 & 13 & .58 \\
\hline efficacy & Control & .92 & 13 & .23 & .88 & 13 & .08 \\
\hline
\end{tabular}

As seen in Table 3, as a result of the Shapiro Wilk normality test, the pretest $\left(\mathrm{SW}_{\text {(experimental) }}=\right.$ $\left..87, p \geq .05, \mathrm{SW}_{\text {(control) }}=.90, p>.05\right)$ and posttest $\left(\mathrm{SW}_{\text {(experimental) }}=.97, p>.05, \mathrm{SW}_{\text {(control) }}=\right.$ $.94, p>.05)$ scores were found to distribute normally. Likewise, in the leadership selfefficacy scale, the pretest $\left(\mathrm{SW}_{\text {(experimental) }}=.94, p>.05, \mathrm{SW}_{\text {(control) }}=.92, p>.05\right)$ and posttest $\left(\mathrm{SW}\right.$ (experimental) $\left.=.95, p>.05, \mathrm{SW}_{\text {(control) }}=.88, p>.05\right)$ scores of the students in the experimental and control groups were also found to distribute normally. The homogeneity of the variances of the groups was examined by Levene's test and the results were presented in Table 4. 
Table 4. The results of Levene's test for equality of variances

\begin{tabular}{llll}
\hline Variable & Measurement & F & $p$ \\
\hline Entrepreneurship & Pretest & .001 & .97 \\
& Posttest & .68 & .42 \\
Leadership self-efficacy & Pretest & 1.66 & .21 \\
& Posttest & 3.21 & .09 \\
\hline
\end{tabular}

As a result of the Levene's test (Table 4), in the scores of entrepreneurship pretest $(\mathrm{F}=.001$, $p>.05)$ and posttest $(\mathrm{F}=.68, p>.05)$ and leadership self-efficacy pretest $(\mathrm{F}=1.66, p>.05)$ and posttest $(\mathrm{F}=3.21, p>.05)$, the variances of the groups were found to be homogeneous. The results of the test of equality of covariance matrices showed that there was no significant difference between the covariance matrices of the groups for the scores obtained from the entrepreneurship scale $(\mathrm{F}=.92, p=.43)$. However, there was a significant difference between the covariance matrices of the groups for the scores obtained from the leadership self-efficacy scale $(\mathrm{F}=4.34, p=.01)$. Therefore, Pillai's Trace criterion was used in the evaluation of the results related to leadership self-efficacy (Can, 2014).

\section{Findings}

First, in order to determine whether the experimental and control groups were equivalent to each other in terms of entrepreneurship and leadership self-efficacy, independent sample $t$ test was conducted for the pretest scores. The results of the independent sample $t$ test were given in Table 5 .

Table 5. The results of independent sample t test for pretest scores of groups

\begin{tabular}{lllllll}
\hline & Groups & $\overline{\mathbf{X}}$ & SD & df & $\boldsymbol{t}$ & $\boldsymbol{p}$ \\
\hline \multirow{2}{*}{ Entrepreneurship } & Experimental & 140.00 & 16.07 & \multirow{2}{*}{24} & \multirow{2}{*}{.07} & .95 \\
& Control & 139.56 & 16.43 & & & \\
Leadership self-efficacy & Experimental & 105.69 & 12.95 & 24 & 1.17 & .25 \\
& Control & 98.46 & 18.16 & 24 & &
\end{tabular}

As seen in Table 5, the results of independent sample $t$ test showed that there was no statistically significant difference between the experimental and control groups in terms of the entrepreneurship $(t=.07, p>.05)$ and leadership self-efficacy $(t=1.17, p>.05)$ pretest scores. So, it can be said that experimental and control groups were statistically equivalent to each other in terms of entrepreneurship and leadership self-efficacy pretest scores. The pretest and posttest mean scores of the students participating in the research for the entrepreneurship scale were given in Table 6 .

Table 6. Pretest and posttest mean scores for the entrepreneurship scale

\begin{tabular}{llllll}
\hline \multirow{2}{*}{ Groups } & $\mathbf{n}$ & Pretest & \multicolumn{3}{l}{ Posttest } \\
\cline { 3 - 6 } & & $\overline{\mathbf{X}}$ & SD & $\overline{\mathbf{X}}$ & SD \\
\hline Experiment & 13 & 140.00 & 16.07 & 149.07 & 14.95 \\
Control & 13 & 139.56 & 16.43 & 136.39 & 10.81 \\
\hline
\end{tabular}

As seen in Table 6, the mean score of the experimental group for the entrepreneurship scale increased from $\bar{X}=140.00, S D=16.07$ in the pretest measurement to $\bar{X}=149.07, S D=14.95$ in the posttest measurement. Whilst the mean score of the control group for the entrepreneurship scale was $\overline{\mathrm{X}}=139.56, \mathrm{SD}=16.43$ in the pretest measurement, it decreased to $\overline{\mathrm{X}}=136.39, \mathrm{SD}=10.81$ in the posttest measurement. Therefore, whereas the mean score for the entrepreneurship increased after the experimental process in the experimental group; it decreased in the control group. In order to be able to test whether the differences in the 
entrepreneurship pretest and posttest mean scores of the groups were statistically significant, a two-factor repeated-measures ANOVA was performed, and the results were given in Table 7.

Table 7. Two-factor repeated-measures ANOVA results of the entrepreneurship pretestposttest scores

\begin{tabular}{lccccc}
\hline Source of the Variance & SS & DF & MS & F & $p$ \\
\hline Between subjects & 1037532.47 & & & & .06 \\
Group (individual / group) & $559.57 \mathrm{~K}$ & 1 & $559.57 \mathrm{~K}$ & 1.50 & \\
Error & 8926.75 & 24 & 371.95 & & .19 \\
Subjects & 2096.31 & & & $.01^{*}$ \\
Measurement (Pretest-Posttest) & 113.13 & 1 & 113.13 & 1,82 & \\
Group*Measurement & 488.00 & 1 & 488.00 & 7.83 & \\
Error & 1495.18 & 24 & 62.30 & & \\
Total & 1039628.78 & 26 & & & \\
\hline
\end{tabular}

As seen in Table 7, as a result of the two-factor repeated-measures ANOVA, it was found that being in different treatment groups had a statistically significant effect on the students' entrepreneurship level $\left(\mathrm{F}_{(1-24)}=7.83, p=.01\right)$. Accordingly, participating in the mentoring program had a statistically significant effect on the increase in the students' entrepreneurship tendency. The pretest and posttest mean scores of the students for the leadership selfefficiency scale were given in Table 8 .

Table 8. Pretest and posttest mean scores for the leadership self-efficiency scale

\begin{tabular}{llllll}
\hline \multirow{2}{*}{ Groups } & \multirow{n}{n}{} & \multicolumn{3}{c}{ Pretest } & \multicolumn{2}{c}{ Posttest } \\
\cline { 3 - 6 } & & $\overline{\mathbf{X}}$ & SD & $\overline{\mathbf{X}}$ & SD \\
\hline Experiment & 13 & 105.69 & 12.95 & 108.83 & 12.58 \\
Control & 13 & 98.46 & 18.16 & 91.11 & 24.55 \\
\hline
\end{tabular}

As can be seen in Table 8, the mean score of the experimental group for the leadership selfefficacy scale increased from $\bar{X}=105.69, \mathrm{SD}=12.95$ in the pretest measurement to $\overline{\mathrm{X}}=$ $108.83, \mathrm{SD}=12.58$ in the posttest measurement. While the mean score of the control group for the leadership self-efficacy scale was $\bar{X}=98.46, \mathrm{SD}=18.16$ in the pretest measurement, it decreased to $\overline{\mathrm{X}}=91.11, \mathrm{SD}=24.55$ in the posttest measurement. In other words, while the mean score for the leadership self-efficacy increased after the experimental process in the experimental group; it decreased in the control group. Two-factor repeated-measures ANOVA was conducted to test whether the differences in the leadership self-efficacy pretest and posttest mean scores of the groups were statistically significant. The two-factor repeatedmeasures ANOVA results were given in Table 9.

Table 9. Two-factor repeated-measures ANOVA results of leadership self-efficacy pretestposttest scores

\begin{tabular}{lcllll}
\hline Source of the Variance & SS & DF & MS & F & $\boldsymbol{p}$ \\
\hline Between subjects & 530704.84 & & & & \\
Group (individual / group) & 2024.18 & 1 & 2024.18 & 5.77 & .02 \\
Error & 8425.71 & 24 & 351.07 & & \\
Subjects & 7093.56 & & & & \\
Measurement (Pretest-Posttest) & 57.64 & 1 & 57.64 & .21 & .65 \\
Group*Measurement & 357.97 & 1 & 357.97 & 1.29 & .27 \\
Error & 6677.95 & 24 & 278.25 & & \\
Total & 537798.4 & 26 & & & \\
\hline
\end{tabular}


As seen in Table 9, as a result of the two-factor repeated-measures ANOVA, it was determined that being in different treatment groups did not have a statistically significant effect on the students' leadership self-efficacy $\left(\mathrm{F}_{(1-24)}=.21, p=.01\right)$. Also, Pillai's Trace criterion was examined (Pillai's Trace $=.051, \mathrm{~F}_{(1-24)}=1.29, p>.05$ ) since the equality of covariance matrix assumption was not met for the leadership self-efficacy. Pillai's Trace criterion showed that the effect of measurement * group was not significant.

\section{Discussion and Conclusion}

In this research, a Volunteer Management Mentoring Program, in which university students were matched with middle or high school students, was carried out in partnership with Kilis 7 Aralik University in Turkey, Kilis Municipality, and UNICEF, and the effect of the program on the entrepreneurship tendency and leadership self-efficacy of the mentor university students was examined. The results revealed that participating in Volunteer Management Mentoring Program was significantly effective on the mentor students' entrepreneurship tendency; however, it had no significant effect on their leadership selfefficacy.

The first finding showed that the mentoring program significantly contributed to the increase in the mentor students' entrepreneurship tendency. Accordingly, participating in the Volunteer Management Mentoring Program provided an increase in the mentor students' behaviors related to entrepreneurship tendency such as perceiving opportunities, taking action to evaluate opportunities, taking risk, contributing to social change, finding solutions to environmental and social problems, and directing individuals (Başol et al., 2011; Mueller \& Thomas, 2001; Özdevecioğlu \& Karaca, 2015; Sarıtaş \& Duran, 2017). Also, it can be said that the Volunteer Management Mentoring Program enabled the mentor students to gain entrepreneur personality traits such as innovativeness, self-confidence, creativity, and achievement motivation (Abdylaev \&Yurekli, 2018; Aydın, 2015; Caliendo \& Kritikos, 2011; Demir \& Demiryurek, 2018; Moore, 2003; Nybakk \& Hansen, 2008; Shane, 2000; Wickham, 2001). The mentor students received training on various subjects such as child rights, working with children and adolescents, communicating with children and adolescents, equality, and empowerment of girls. After that, they communicated with the middle school or high school students, organized activities they could do together, and interacted with different institutions for event organizations throughout the 9-week Volunteer Management Mentoring Program. Thereupon, it can comfortably be said that the Volunteer Management Mentoring Program allowed the mentor students to take entrepreneurial actions in daily life. Moreover, the mentor students had opportunities to exhibit entrepreneurial behaviors throughout the program, and so their entrepreneurship tendencies increased at the end of the program. Another finding showed that participating in the Volunteer Management Mentoring Program had no significant effect on the students' personal competence beliefs that they can gather individuals around a goal, direct individuals, and achieve common goals (Cansoy \& Polatcan, 2018). However, in the posttest measurement, the leadership self-efficacy scores of the mentor students in experimental group increased, although not statistically significantly. It is worthy of note that no increase was observed in the control group in this regard. In fact, the leadership self-efficacy scores of the students in the control group decreased in the posttest measurement. Hence, based on this finding, it can be asserted that the Volunteer Management Mentoring Program can be beneficial in preserving the existing positive beliefs, but it does not ensure a significant increase in leadership self-efficacy beliefs. To put it in a different way, it seems important to provide the university students with environments and opportunities in which they can use their leadership skills to sustain their positive beliefs 
about leadership skills.

One of the factors that determine self-efficacy beliefs is one's own experiences (Bandura, 1986). Accordingly, the increase in the leadership self-efficacy scores of the experimental group in the posttest measurement can be explained by the mentor students' personal experiences in the Volunteer Management Mentoring Program. Throughout the program, they tried to lead the mentee students by using their leadership skills. While the mentor students felt that they were successful in using their leadership skills in some activities; they might have had difficulties in some others. Especially at the beginning of the program, the mentor students might have experienced more difficulty in managing, guiding and persuading the mentee students. As the program progresses, the students may be more competent in using their leadership skills and their leadership self-efficacy beliefs may begin to increase. However, the mentor students had to lead the mentee students just for 6 weeks. Whence, it can be thought that there were a limited number of experiences where the mentor students could use their leadership skills effectively. For this reason, the Volunteer Management Mentoring Program might not have provided a statistically significant increase in the mentor students' leadership self-efficacy beliefs.

Entrepreneurship and leadership are important skills for young people in 21st century (Partnership for 21st Century Skills, 2009), and mentoring practices can help young people gain these skills. To the best of our knowledge, in the Turkish literature, there is no study examining the effect of a mentoring program in which university students are matched with middle or high school students. The previous mentoring studies generally focused on the effect of mentoring programs on mentees and asserted that they produced positive outcomes for them (e.g. Çamveren \& Kocaman, 2019; İşcan \& Çakır, 2016, Özdemir \& Özan, 2013; Tezel Baydar, Gülhan, \& Danayiyen, 2020). The current study evidenced that mentoring programs could be beneficial for mentors, too.

This study revealed that mentoring the middle and high school students helped the university students develop more positive attitudes toward entrepreneurship. Based on this result, it is recommended to enhance the mentoring practices in universities. It might be helpful to offer students who lack entrepreneurial characteristics the opportunity to become a mentor. In a recent study, it has been unearthed that many university students have limited opportunities to experience leadership, although leadership experiences not only help students to develop their skills in taking responsibility, undertaking, team building, managing and developing collaboration between teams, but also provide a basis for future great work (Öz \& Baloğlu, 2020). To that end, mentoring practices can be used to give university students an opportunity to experience leadership.

Desite the fact that this study provides valuable results, it has some limitations. The first is that the study is only quantitative and designed as a semi-experimental study. It is recommended that full experimental studies with qualitative dimension be carried out in future. As this study was carried out in cooperation with UNICEF and the municipality, only female students were included in the mentoring program in line with their requests, and thence the experimental group consisted entirely of female students. In the control group, male students were also included since there was not sufficient number of female students volunteering to participate in the study. Due to this, gender distribution in the experimental and control groups was not equal. In future studies, it may be beneficial to form gender-wise equal groups so as to.... This study focused on the effect of mentoring program on mentor students. In the future, the effect of the Volunteer Management Mentoring Program on 
mentee students can be investigated.

\section{Acknowledgments}

This article is supported by Kilis 7 Aralik University Scientific Research Projects Coordination. Project No: 19-12512. We would like to thank the Scientific Research Projects Coordination for their support.

\section{References}

Abdyldaev, M., \& Yürekli, E. (2018). Entrepreneurial perceptions of university students, a research on the faculty of economics and administrative sciences students of KTMU. International Conference on Eurasion Economies, 179-187. Retrieved from https://www.avekon.org/papers/2168.pdf

Allen, T. D., Eby, L. T., \& Lentz, E., (2006). Mentorship behaviors and mentorship quality associated with formal mentoring programs: Closing the gap between research and practice. Journal of Applied Psychology, 91(3), 567-578. doi: $\underline{10.1037 / 00219010.91 .3 .567}$

Anagün, Ş. S., Atalay, N., Kılıç, Z., \& Yaşar, S. (2016). The development of a 21st century skills and competences scale directed at teaching candidates: Validity and reliability study. Pamukkale University Journal of Education,40(40), 160-175. doi: 10.9779/PUJE768

Ananiadou, K., \& Claro, M. (2009). 21st century skills and competences for new millennium learners in OECD countries. OECD Education Working Papers, No. 41, OECD Publishing. doi:10.1787/218525261154

Aydin, E. (2015). Investigating the characteristics of entrepreneurial personality that were included in social studies curriculum and evaluating upskilling of these characteristics. (Unpublished Master Thesis). Sakarya University, Institute of Educational Sciences, Sakarya.

Balaban, Ö., \& Özdemir, Y. (2008). The effect of entrepreneurship education on entrepreneurship tendency: Sakarya University example. Journal of Entrepreneurship and Development, 3(2), 133-147. Retrieved from http://acikerisim.lib.comu.edu.tr:8080/xmlui/handle/COMU/952.

Bandura, A. (1986). Social foundations of though and action: A social cognitive theory. Englewood Cliffs, N.J: Prentice-Hall.

Bandura, A. (1994). Self-efficacy. In V. S. Ramachaudran (Ed.), Encyclopedia of human behaviors, (pp.71-81.). NewYork: Academic Press.

Bandura, A., Caprara, G. V., Barbaranelli, C., Pastorelli, C., \& Regalia, C. (2001). Sociocognitive self-regulatory mechanisms governing transgressive behavior. Journal of Personality and Social Psychology, 80, 125-135. doi: 10.1037//O022-3514.80.1.125

Barker, E.R. (2006). Mentoring - a complex relationship, Journal of the American Academy of Nurse Practicioners, 18, 56-61. doi 10.1111/j.1745-7599.2006.00102.x

Başol, O., Dursun, S., \& Aytaç, S. (2011). The effect of personality on entrepreneurship intention: An application on university youth "Is, Guc" Industrial Relations and Human Resources Journal, 13(4), 7-22. doi: 10.4026/1303-2860.2011.186.x

Bobbio, A. \& Manganellii, A. M. (2009). Leadership self-efficacy scale: A new multidimensional instrument. TPM-Testing, Psychometrics, Methodology in Applied Psychology, 16(1), 3-24. Retrieved from https://www.tpmap.org/wpcontent/uploads/2014/11/16.1.1.pdf 
Buschlen, E. \& Dvorak, R. (2011). The social change model as pedagogy: Examining undergraduate leadership growth. Journal of Leadership Education, 10(2): 38-56. doi: 10.12806/V10/I2/RF2

Büyüköztürk, S. (2013). Data analysis handbook for social sciences. Ankara: Pegem Academy Publishing.

Caliendo, M. \& Kritikos, A. (2011). Searching for the entrepreneurial personality: New evidence and avenues for further research. Iza Discussion Paper No.5790, Institute of Labor Economics (IZA).

Can, A. (2014). Quantitative data analysis in the scientific research process with SPSS. Ankara: Pegem Academy Publishing.

Cansoy, R. (2018). 21st century skills according to international frameworks and building them within the education system. Journal of the Human and Social Science Researches, 7(4), 3112-3134. doi: 10.15869/itobiad.494286

Cansoy, R., \& Polatcan, M. (2018). Adapting leadership self-efficacy scale into Turkish culture: Validity and reliability study. PESA International Journal of Social Studies, 4(4), 331-342. doi: 10.25272/j.2149-8385.2018.4.4.01

Çamveren, H. \& Kocaman , G. (2019). A literature review on the effect of the mentoring program on nurses' turnover and retention. Dokuz Eylul University E-Journal of Nursing Faculty, 12(2), 152-160.

Damar, A. (2015). The impact of entrepreneurship personality characteristics on entrepreneurhip tendency of students:A comparative study at Sannio and Selcuk Universities. (Unpublished Master Thesis), Selçuk University, Institute of Social Sciences, Konya.

Demir, H. \& Demiryürek, K. (2018). Determination of entrepreneurship tendencies of university students: The case of OMU Faculty of Agriculture. Journal of Agriculture and Nature, 21(Special issue): 168-176. doi: 10.18016/ksutarimdoga.vi.472966

Ekiz, D. (2003). Introduction to research methods and methods in education: Qualitative, quantitative and critical theory methodologies. Ankara: Pegem Academy Publishing.

Eren, E. (2004). Organizational behavior and management psychology. Istanbul: Beta Publishing.

Gay, L. R., Mills, G. E. \& Airasian, P. (2005). Educational research: Competencies for analysis and application (8rd ed.). Upper Saddle River, NJ: Pearson Education.

Germaine, R., Richards, J., Koeller, M., \& Schubert-Irastorza, C. (2016). Purposeful use of 21 st century skills in higher education. Journal of Research in Innovative Teaching, 9(1), 19-29.

İşcan, Ö.F. \& Çakır, S. (2016). The effect of mentoring and psychological empowerment on self efficacy perception. Suleyman Demirel University The Journal of Faculty of Economics and Administrative Sciences, 21(1), 1-15.

Krug, S.E. (1992). Instructional leadership, school instructional climate, and student learning outcomes. Urbana, IL: National Center for School Leadership, 1-30.

Külekçi, E. (2015). An experimental study about developing undergraduate students' socially responsible leadership skills. (Unpublished Doctoral Thesis), Gaziantep University, Institute of Educational Sciences, Gaziantep.

Lo, M., Thurasamy, R., \& Liew, W.T. (2014). Relationship between bases of power and job stresses: role of mentoring. Springer Plus, 3, 432. doi: 10.1186/2193-1801-3-432

Moore, T.W.(2003). Applying cognitive processes to franchisees: the use of entrepreneurial measures to study franchisee response to constraints. (Unpublished Doctoral Thesis), University of Cincinati, UMI, no: 3093381, p.3-217

Morris, M. H., Kuratko, D. F., \& Covin, J. G. (2011). Corporate entrepreneurship \& innovation (3rd ed.). Mason, OH: South-Western/Thomson Publishers. 
Mueller, S. L., \& Thomas, A. S. (2001). Culture and entrepreneurial potential: a nine country study of locus of control and innovativeness. Journal of Business Venturing, 16(1), 51-75. doi: 10.1016/S0883-9026(99)00039-7

Ng, K. Y., Ang, S., \& Chan, K. Y. (2008). Personality and leader effectiveness: a moderated mediation model of leadership self-efficacy, job demands, and job autonomy. Journal of Applied Psychology, 93(4), 733-743. doi: 10.1037/0021-9010.93.4.733

Nybakk, E. \& Hansen, E. (2008). Entrepreneurial attitude, innovation and performance among Norwegian nature-based tourism enterprises. Forest Policy and Economics, 10(7-8), 473-479. doi: 10.1016/j.forpol.2008.04.004

Öz, H. \& Baloğlu, N. (2020). Analysis of students' experiences of leadership in educational levels. Gazi University Journal of Gazi Educational Faculty, 40(1), 139-158.

Özdemir, A., Özgüner, M., \& Alkış, H. (2018). How does entrepreneurship education given at universities affect the entrepreneurial personality traits? An experimental. Selcuk University Vocational School of Social Sciences Journal, 21(2), 430-447.

Özdemir, T. Y. \& Özan, M. B. (2013). The effects of e-mentorship process on mentee achievement. Bartın University Journal of Faculty of Education, 2(1), 170-186.

Özdevecioğlu, M. \& Karaca, M. (2015). Entrepreneurship, entrepreneurial personality, concept and application. Konya: Education Publishing.

Paglis, L.L. \& Green, G. S. (2002). Leadership self-efficacy and managers' motivation for leading change. Journal of Organizational Behavior, 23(1), 215-235. doi: 10.1002/job.137

Partnership for 21st Century Skills (2009). P21 framework definitions. Retrieved from https://files.eric.ed.gov/fulltext/ED519462.pdf (25/05/2020).

Rackham Graduate School (2012a). How to get the mentoring you want: A guide for graduate students. Ann Arbor, MI: University of Michigan Press.

Rackham Graduate School (2012b). How to mentor graduate students: A guide for faculty. The Regents of the University Students. Ann Arbor, MI: University of Michigan Press.

Riera, J.L. (2009). Applying the social change model. In: Leadership for a better world understanding the social change model of leadership development. Komives, S.R. and Wagner, W. (Ed.). Jossey Bass, U.S.A. pp: 79-100.

Robyn, P. (2005). To lead others, first know yourself. Education Today, pp. 13-15.

Rubenstein, M.G. (2013). Know yourself, in order to lead others. Army Medical Department Journal. pp. 30-32.

Sarıtaş, A. \& Duran, G. (2017). A research to determine the entrepreneurial tendency of university students. Journal of Social Sciences of Muş Alparslan University, 5(1), 147165. doi: 10.18506/anemon.285116

Shane, S. (2000). Prior knowledge and the discovery of entrepreneurial opportunities. Organisational Science, 11(4), 448-169. doi: 10.1287/orsc.11.4.448.14602

Silva, E. (2009). Measuring skills for 21st-century learning. Phi Delta Kappa International, 90(9), 630-634.

Tezel Baydar, Y., Gülhan, Y. B., \& Danayiyen, A. (2020). Analyzing the relationship between the physician assistants' perceptions of mentorship and their self-efficacy: A sample from Izmir province. Online Turkish Journal of Health Sciences, 5(1), 93-105.

Tuncer, M., \& Doğan, S. (2018). The impact of entrepreneurship education in the entrepreneurship tendency: A research on tourism managements students. Tourism Academic Journal, 5(2), 97-108.

Uygun, M., \& Güner, E. (2016). The role of entrepreneurship education in development of entrepreneurial intent. MANAS Journal of Social Studies, 5(5), 37-57. 
Wickham, P. A. (2001). Strategic entrepreneurship: A decisionmaking approach to need venture creation and management. Financial Times. Prentice Hall.

Williams, J.R., Townsend, C.D., \& Linder, J.R. (2005). Teaching leadership: Do students remember and utilize the concepts we teach? Journal of Leadership Education, 4(1), 61-73. doi: $10.12806 / \mathrm{v} 4 \% 2$ Fi1\%2Frf2

Y1lmaz, E. \& Sünbül, A.M. (2009). Developing scale of university students entrepreneurship. Selçuk University The Journal of Institute of Social Sciences, 21, 195-203. 